\title{
Lake Worth Bottom Sediments-A Chronicle of Water-Quality Changes in Western Fort Worth, Texas, 1914-2001
}

\section{Fish-Consumption Advisory Issued Because of Elevated PCBs}

In spring 2000, the Texas Department of Health issued a fishconsumption advisory for Lake Worth, Tex., because of elevated concentrations of polychlorinated biphenyls (PCBs) in fish (Texas Department of Health, 2000). In response to the advisory and in cooperation with the U.S. Air Force, the U.S. Geological Survey (USGS) collected 21 surficial samples and three deeper gravity core samples from the sediment deposited at the bottom of Lake Worth. The purpose of that study was to assess the spatial distribution and historical trends of selected hydrophobic contaminants, including PCBs, and to determine, to the extent possible, sources of selected metals and hydrophobic organic contaminants (HOCs) to Lake Worth. Hydrophobic (literally "water fearing") contaminants tend to chemically adsorb to soils and sediments. Fifteen of the top 20 contaminants on the Agency

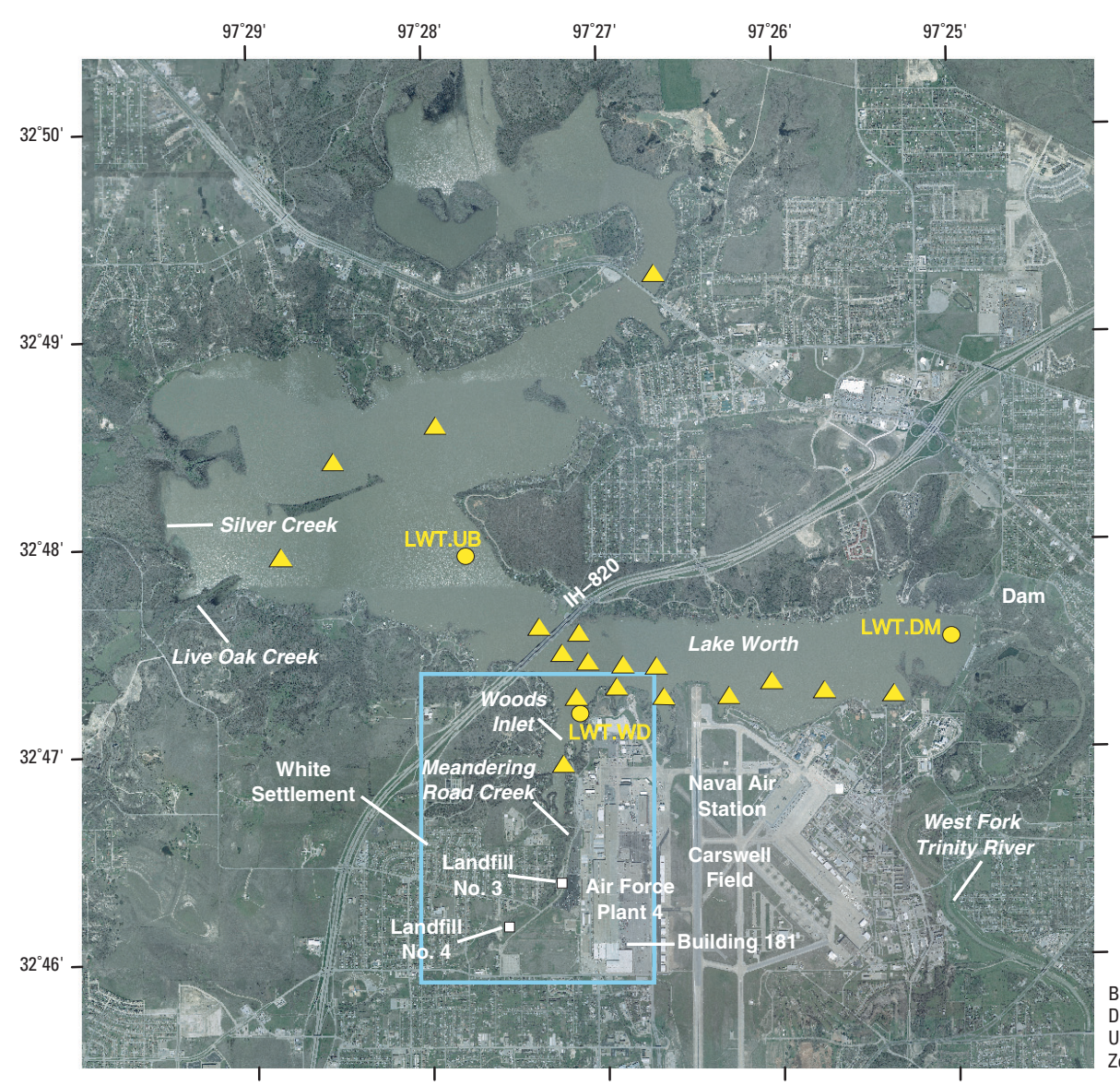

Figure 1. Location of study area and approximate sampling locations in Lake Worth, Fort Worth, Texas, 20002001. for Toxic Substances and Disease Registry (2001) priority list of hazardous substances are hydrophobic.

Chemical analysis of sediment cores is one method that can be used to determine trends in HOCs such as PCBs. As sediments accumulate in lakes and reservoirs, they generate a partial historical record of water quality. This fact sheet describes the collection of sediment cores, age-dating methods, and historical trends in PCBs in Lake Worth sediments. The fact sheet also describes the spatial distribution of PCBs in surficial sediments and concludes with objectives for the second phase of data collection and the approach that will be used to achieve these objectives. The USGS published a comprehensive report on the first phase of the study (Harwell and others, 2003).

Lake Worth is a reservoir on the West Fork Trinity River on the western edge of Fort Worth in Tarrant County. In 1914, the City of Fort Worth completed the reservoir to serve as a municipal water supply. Lake Worth has a surface area of 13.2 square kilometers and a storage capacity of 47 million cubic meters. The drainage area to the reservoir is 5,350 square kilometers (Ruddy and Hitt, 1990).

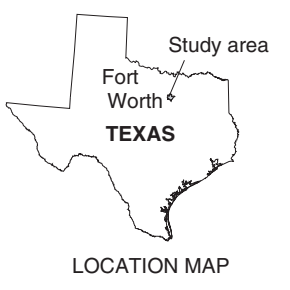

0.5 KILOMETER

\section{EXPLANATION}

Area enlarged in figure 5

Box-core sampling site/gravity-core sampling site and identifier

Box-core sampling site The surrounding area to the south and east is primarily urban, and the area to the north and northwest is mostly residential.

\section{Collection of Sediment Cores}

Surficial sediment samples (top 2 centimeters) were collected at 21 sites using a box corer. The sites were distributed throughout the lake (fig. 1) to include areas along the shoreline adjacent to Air Force Plant 4 (AFP4) and Naval Air Station-Joint Reserve Base Carswell Field, the mouths of major tributaries,

Base modified from U.S. Geological Surve Digital orthophoto quarter-quadrangle, Universal Transverse Mercator projection, areas near the dam that are influenced by all sources of contaminants 


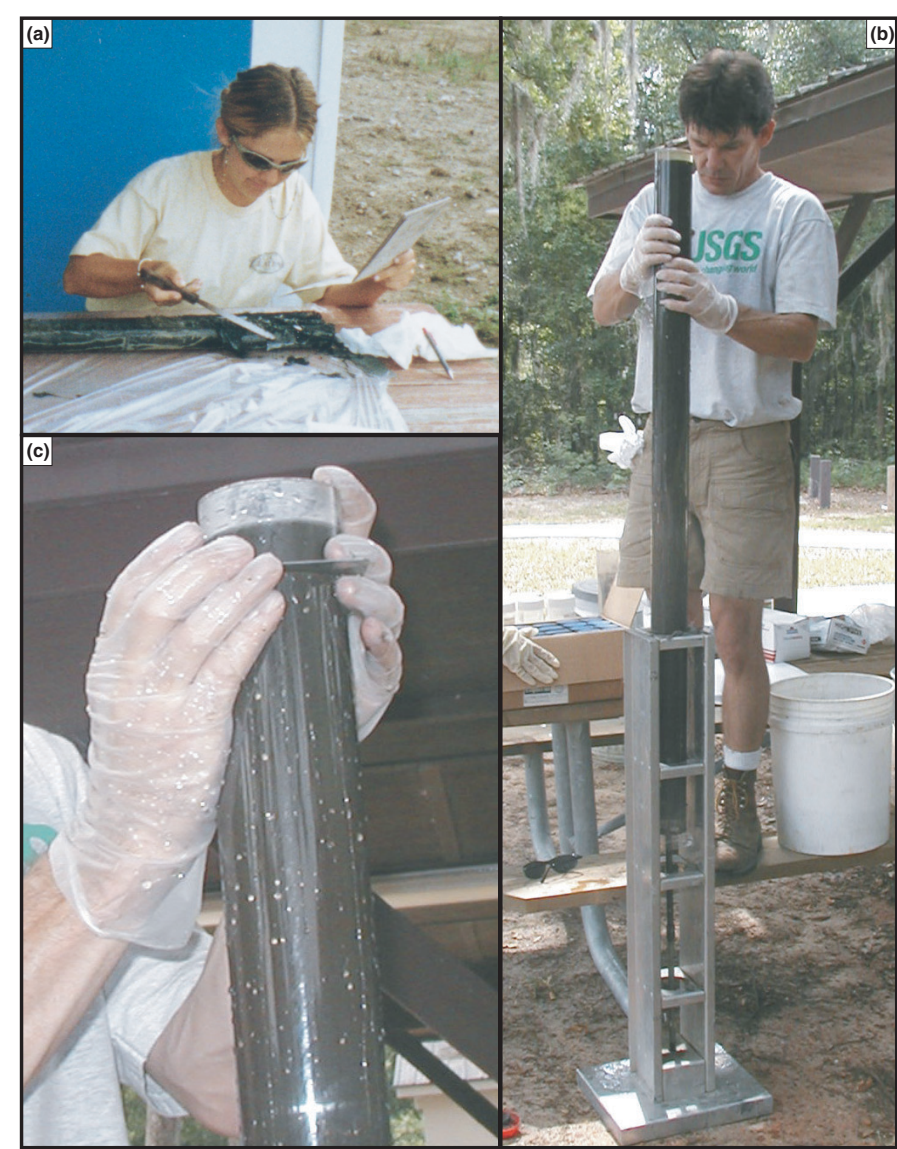

Figure 2. U.S. Geological Survey personnel (a) describing a gravity core, (b) placing gravity core in core extrusion stand, and (c) slicing a subsample from a gravity core (photographs by Barbara J. Mahler, U.S. Geological Survey).

to the lake, and areas in the upper part of the lake not affected by AFP4 and Carswell Field and less affected by urbanization.

At three sites where surficial sediment samples were collected, gravity cores were collected to investigate historical trends in selected contaminants. One gravity core was collected in the upper part of the lake upstream from the IH-820 bridge (LWT.UB, fig. 1) to represent historical trends in a reference site upstream from AFP4 and much of the urban influence to the lake. A second gravity core was collected in Woods Inlet (LWT.WD, fig. 1) near the mouth of Meandering Road Creek to represent a site influenced by runoff from AFP4. A third gravity core was collected in the lower part of the lake near the dam (LWT.DM, fig. 1) to represent a site influenced by all inputs of contaminants to the lake.

One gravity core from each site was split lengthwise and described visually on site (fig. 2a). A second core from each site was extruded vertically (fig. 2b), and discrete intervals were subsampled for chemical analysis (fig. 2c). Box-core samples were analyzed for the same constituents as gravity-core samples except for cesium-137 $\left({ }^{137} \mathrm{Cs}\right)$, which was used in age dating the gravity cores. Results of all chemical analyses are presented in Harwell and others (2003).

\section{Age-Dating Methods}

The pre-reservoir boundary (dated as 1914, when the dam was completed), the sampling date in 2000 , and profiles of radioactive ${ }^{137} \mathrm{Cs}$ were used in age dating the gravity cores. In reservoir sediment cores, sediment deposited after the lake formed is easy to distinguish from pre-reservoir soils because pre-reservoir soils are relatively dry and can contain sand and root hairs. Because ${ }^{137} \mathrm{Cs}$ sorbs strongly to fine-grained sediments, it is useful for dating sediments exposed to atmospheric fallout, such as those found in lakes (Durrance, 1986). Beginning in about 1952, large-scale nuclear weapons testing released detectable amounts of ${ }^{137} \mathrm{Cs}$ to the atmosphere. Concentrations of ${ }^{137} \mathrm{Cs}$ in the atmosphere peaked between 1963 and 1964. Profiles of ${ }^{137} \mathrm{Cs}$ activity in gravity cores can provide two date markers in reservoirs built before about 1950 — the first occurrence between 1952 and 1953 and the peak in 1964. Other chemical indicators also can be used to corroborate age assignments made using ${ }^{137} \mathrm{Cs}$; these include peaks in DDT and lead concentrations. Total DDT (the sum of DDT and its breakdown products) concentrations tend to peak in the early-to-mid-1960s, coincident with peak use of DDT in the United States (Van Metre and Callender, 1997). Lead concentrations in urban lake and reservoir sediment cores consistently peaked in the mid1970s coinciding with the switch from leaded to unleaded gasoline (Callender and Van Metre, 1997). All of these indicators were used to assign dates to core samples and to investigate the reasonableness of date assignments. Ages for samples at depth intervals between known depth-date markers were assigned on the basis of a mass accumulation rate (MAR) because MARs automatically adjust for compaction in a core.

The ${ }^{137} \mathrm{Cs}$ activity profiles in each of the three gravity cores indicate different sedimentation rates for each of the sites (fig. 3 ). Core LWT.UB has an unusual ${ }^{137} \mathrm{Cs}$ profile with nondetections in
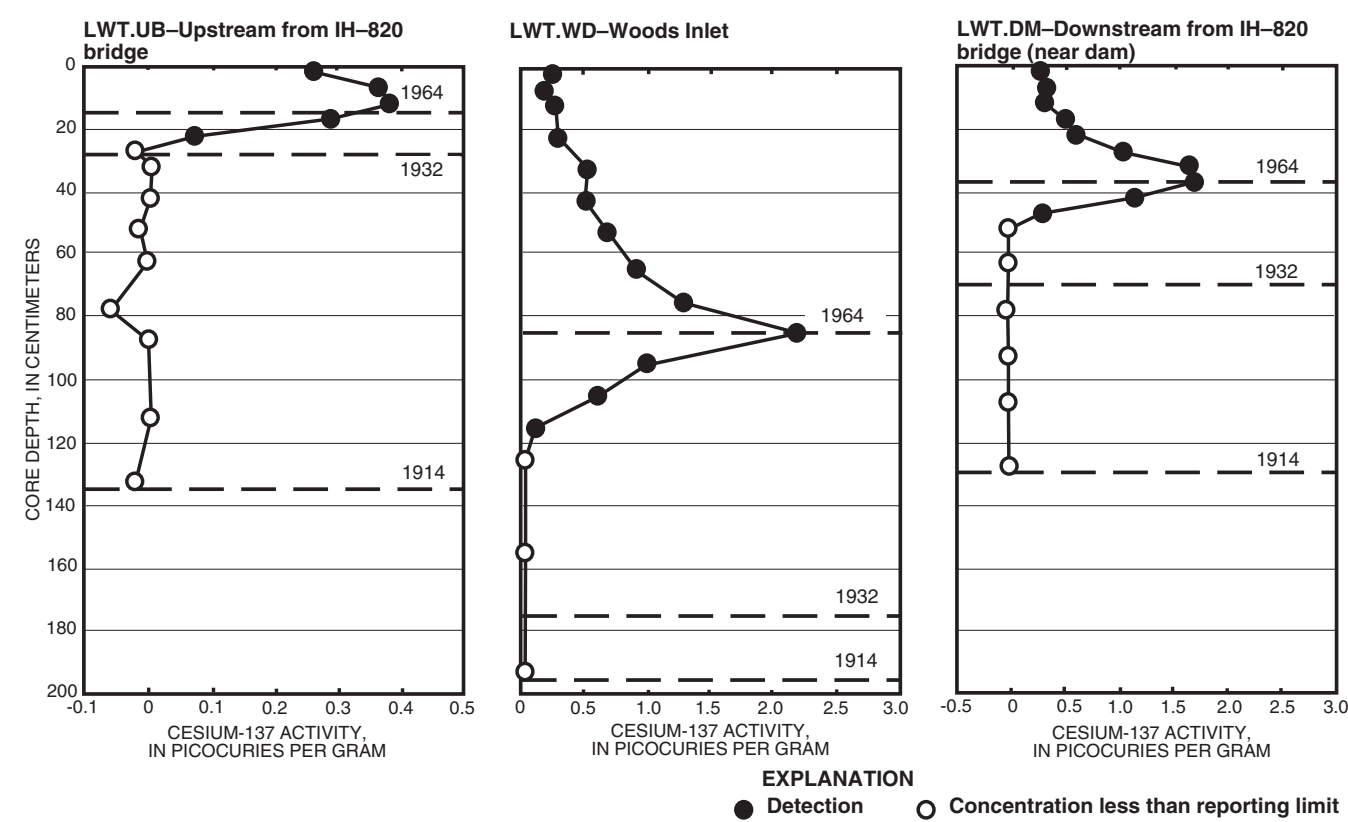

Figure 3. Cesium-137 profiles in gravity-core samples from Lake Worth, Fort Worth, Texas, 2000-2001. 


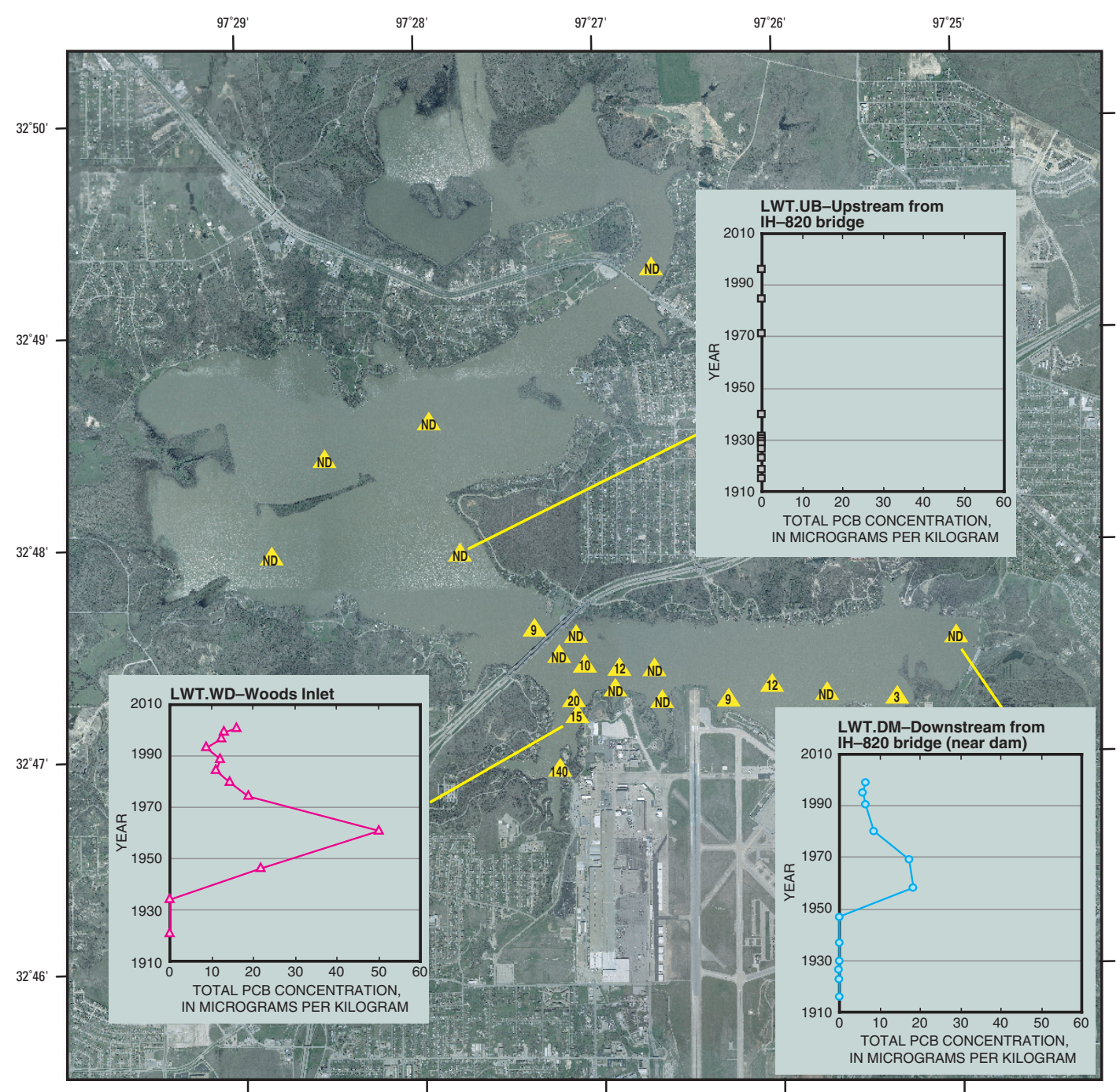

Figure 4. Spatial and temporal distribution of total polychlorinated biphenyls (PCBs) in sediments from Lake Worth, Fort Worth, Texas, 2000-2001.

most of the lower part of the core and a low-activity, rounded peak in the top 20 centimeters of the core. The construction of Eagle Mountain Lake immediately upstream from Lake Worth on the West Fork Trinity River in 1932 provides a logical explanation for this seemingly anomalous profile. Eagle Mountain Lake has a conservation storage capacity about five times greater than that of Lake Worth and captures nearly all of the runoff from the watershed of Lake Worth. As a result, sedimentation rates probably declined substantially after 1932, especially in the upper part of the lake upstream from the larger tributary inflows. The ${ }^{137} \mathrm{Cs}$ activity profile in core LWT.DM indicated a similar temporal pattern, but with a much less pronounced difference in MAR before and after Eagle Mountain Lake was formed. Core LWT.WD has a ${ }^{137} \mathrm{Cs}$ profile characterized by a distinct first occurrence and sharp peak, a smooth exponential decrease above the peak, and a large peak-to-top-of-core concentration ratio (Van Metre and Callender, 1997).

\section{Historical Trends in PCBs}

PCBs were widely used in both industrial and urban applications in the United States from the 1950s to the 1970s. Because of their toxicity and environmental persistence, $\mathrm{PCB}$ manufacture and use was restricted by the U.S. Environmental Protection Agency in 1971. PCB
Total PCBs were not detected in any of the upper-lake surficial (box-core) samples (fig. 4). Seven of the 13 surficial samples from the middle and lower lake had detectable total PCB concentrations (all less than the laboratory reporting level) with a maximum estimated concentration of 12 micrograms per kilogram $(\mu \mathrm{g} / \mathrm{kg})$. The three surficial samples from Woods Inlet had estimated total PCB concentrations of 15,20 , and $140 \mu \mathrm{g} / \mathrm{kg}$, with the highest concentration at the farthest upstream site in Woods Inlet.

The gravity cores indicate a clear picture of temporal trends in total PCB concentrations (fig. 4). No detections occurred in samples in the upper-lake core (LWT.UB) or in samples deposited before the late 1940s in either the near-dam core (LWT.DM) or the Woods Inlet core (LWT.WD). The peak concentration in both the near-dam core and the Woods Inlet core occurred in the 1960s, followed by an exponential decrease to the top of the core. In both cores, the peak concentration was about three times greater than the estimated concentration at the top of the core. Despite decreases in recent years, these trends suggest that PCBs continue to enter the lake, probably attached to suspended sediment during runoff. These trends also suggest that larger concentrations could occur in deeper sediments farther upstream from the most upstream site in Woods Inlet, where the surface concentration was $140 \mu \mathrm{g} / \mathrm{kg}$. 


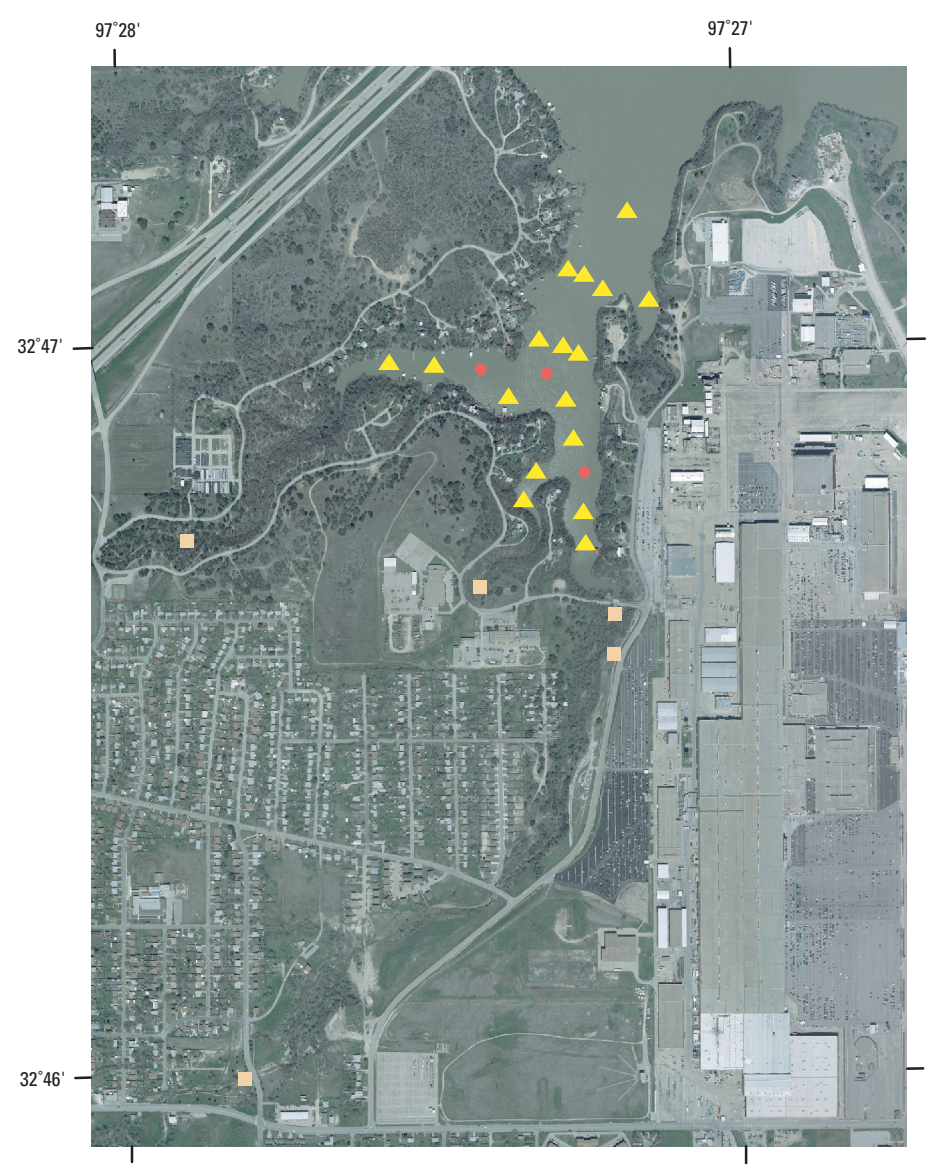

Figure 5. Approximate sampling locations for second round of sampling in and near Woods Inlet of Lake Worth, Fort Worth, Texas, 2000-2001.

\section{Study Continued}

The results from this study provided much information but raised new questions about the extent and sources of PCB contamination in Lake Worth sediments. To answer these new questions, a second round of sampling was done. The second round of sampling had two principal objectives: The first objective was to map the extent of sediments with elevated concentrations of PCBs (greater than about $20 \mu \mathrm{g} / \mathrm{kg}$ ) in Woods Inlet. The second was to determine likely sources of PCBs to sediments entering Woods Inlet from AFP4 and from Meandering Road Creek and other small tributaries.

To address these objectives, additional sediment samples were collected. Surficial sediment samples from 17 new sites and gravity cores from three new sites were collected in Woods Inlet (fig. 5). A congener-specific PCB analysis was done on both the bottomsediment samples and on suspended-sediment samples in an attempt to chemically "fingerprint" PCBs from different sources. The USGS has pioneered the use of large-volume suspended-sediment (LVSS) sampling for HOCs, such as PCBs (B.J. Mahler, U.S. Geological Survey, written commun., 2003). The technique is useful to detect and quantify HOCs in stormwater where traditional water sampling and streambedsediment sampling have yielded poor results. LVSS sampling sites were established at five locations (fig. 5) where flow enters Woods Inlet from AFP4 and the surrounding (upstream) urban area. The LVSS sampling was done using passive samplers, a low-tech but effective and inexpensive way to get large-volume (25-liter), firstflush stormwater samples. LVSS samples were collected for three storms at each site. Bed sediments were collected from the creek bottoms at four of the five tributaries adjacent to LVSS sampling sites. PCB concentrations and congener mixtures at each site relative to the drainage area and to the occurrence of PCBs in lake-bottom sediment samples will be used to try to determine sources of PCBs to Lake Worth.

\section{References}

Agency for Toxic Substances and Disease Registry, 2001, Top 20 hazardous substances-ATSDR/EPA priority list for 2001: accessed January 23, 2002, at URL

http://www.atsdr.cdc.gov/cxcx3.html

Callender, Edward, and Van Metre, P.C., 1997, Reservoir sediment cores show U.S. lead declines: Environmental Science and Technology, v. 31, no. 9, p. $424 \mathrm{~A}-428 \mathrm{~A}$.

Durrance, E.M., 1986, Radioactivity in geology—Principles and applications: Chichester, West Sussex, England, Ellis Horwood Limited, 441 p.

This fact sheet is based on the report

Harwell, G.R., Van Metre, P.C., Wilson, J.T., and Mahler, B.J., 2003, Spatial distribution and trends in trace elements, polycyclic aromatic hydrocarbons, organochlorine pesticides, and polychlorinated biphenyls in Lake Worth sediment, Fort Worth, Texas: U.S. Geological Survey Water-Resources Investigations Report 03-4269, 56 p.

- Christopher L. Braun and Glenn R. Harwell

Any use of trade, product, or firm names is for descriptive purposes only and does not imply endorsement by the U.S. Government.
Ruddy, B.C., and Hitt K.J., 1990, Summary of selected characteristics of large reservoirs in the United States and Puerto Rico, 1988: U.S. Geological Survey Open-File Report 90-163, 295 p.

Texas Department of Health, 2000, TDH warns against eating fish from Lake Worth: Texas Department of Health news release, April 19, 2000, accessed July 15, 2003, at URL http://www.tdh.state.tx.us/news/b_new308.htm

Van Metre, P.C., and Callender, Edward, 1997, Water-quality trends in White Rock Creek Basin from 1912-1994 identified using sediment cores from White Rock Lake reservoir, Dallas, Texas: Journal of Paleolimnology, v. 17, p. 239-249.

Van Metre, P.C., Callender, Edward, and Fuller, C.C., 1997, Historical trends in organochlorine compounds in river basins identified using sediment cores from reservoirs: Environmental Science and Technology, v. 31, no. 8, p. 2,339-2,344.

Van Metre, P.C., Wilson, J.T., Callender, Edward, and Fuller, C.C., 1998, Similar rates of decrease of persistent, hydrophobic and particle-reactive contaminants in riverine systems: Environmental Science and Technology, v. 32, no. 21, p. 3,312-3,317.
Information on technical reports and hydrologic data related to this study can be obtained from:

District Chief

U.S. Geological Survey

8027 Exchange Dr.

Austin, TX 78754-4733

E-mail: dc_tx@usgs.gov
Phone: (512) 927-3500

FAX: (512) 927-3590

World Wide Web:

http://tx.usgs.gov/ 